\title{
Regulation of estrogen receptor- $\alpha$ expression by the tumor suppressor gene p53 in MCF-7 cells
}

\author{
S V Angeloni, M B Martin ${ }^{1}$, P Garcia-Morales ${ }^{2}$, \\ M D Castro-Galache ${ }^{3}$, J A Ferragut ${ }^{3}$ and M Saceda $^{2,3}$
}

Centre for Vaccine Development, University of Maryland School of Medicine, Baltimore, Maryland 21201, USA

${ }^{1}$ Departments of Oncology and Biochemistry and Molecular Biology, Vincent T Lombardi Cancer Center, Georgetown University, Washington DC 20007, USA

${ }^{2}$ Hospital General Universitario de Elche, 03202 Elche, Alicante, Spain

${ }^{3}$ Instituto de Biología Molecular y Celular, Universidad Miguel Hernandez, 03202 Elche, Alicante, Spain

(Requests for offprints should be addressed to M Saceda, Centro de Biologia Molecular y Celular, Ed. Torregaitan, Universidad Miguel Hernández, 03202 Elche, Alicante, Spain; Email: msaceda@umh.es)

\begin{abstract}
The results presented here demonstrate that p53 upregulates estrogen receptor- $\alpha(E R \alpha)$ expression in the human breast cancer cell line MCF-7. Two approaches were used to alter the activity of p53 in the cells. In the first approach, stable transfectants expressing an antisense p53 were established. In the stable clones, expression of antisense 553 resulted in a decrease in the expression of ER $\alpha$ protein. In the second approach, MCF-7 cells were transiently transfected with wild-type p53. Overexpression of p53 increased the amount of ER $\alpha$. To determine whether the effects of p53 on the expression of ER $\alpha$ were
\end{abstract}

due to changes in transcription, deletion mutants of the ER $\alpha$ promoter were used. This experimental approach demonstrated that p53 up-regulates ER $\alpha$ gene expression by increasing transcription of the gene through elements located upstream of promoter A. Transfection assays using p53 mutants further demonstrated that the p53-induced increase in ER $\alpha$ gene transcription was not dependent on the ability of p53 to bind to DNA but on its ability to interact with other proteins.

Journal of Endocrinology (2004) 180, 497-504

\section{Introduction}

Several clinical observations have been made which indicate a role for estrogen and the estrogen receptor (ER) in the development and progression of breast cancer. As a result, measurement of tumor ER content is one of the parameters used to predict the therapeutic benefit of anti-hormonal therapy. However, this correlation is not perfect; while more than $60 \%$ of human breast cancers are ER positive, only two-thirds of these cases are responsive to anti-estrogen therapy (Allegra \& Lippman 1980, DeSombre \& Jensen 1980, Osborne et al. 1980, Paridaens et al. 1980). In addition, ER-positive patients eventually develop ER-negative and hormone-independent tumors. The molecular mechanisms responsible for the progression from a hormone-dependent to a hormone-independent phenotype are not well understood.

There is substantial evidence showing that alterations in the tumor suppressor gene, p53, are associated with the development of several types of cancer, including breast cancer (Baker et al. 1990, Hollstein et al. 1991). Induction of $\mathrm{p} 53$ activity can be mediated by a variety of agents that damage DNA, and $\mathrm{p} 53$ is believed to function by arresting cell cycle progression to allow the repair of DNA damage or the induction of apoptosis (Zhan et al. 1993, YonishRouach et al. 1995). Recent data also show that p53 can be activated by compounds that stabilize microtubules, such as taxol (Tishler et al. 1995). The mechanism of p53 action is due to its ability to function as a transcription factor to either activate or repress expression of a number of genes (Ludes-Meyers et al. 1996, Velculescu \& El Deiry 1996, Wang et al. 2001). The ability of p53 to regulate gene expression is mediated by binding to DNA either directly or through its interaction with other transcription factors such as the TATA binding protein, CCAAT binding protein, SP1, and other transcription factors (Velculescu \& El Deiry 1996). One of the genes that is regulated by $\mathrm{p} 53$ is the multidrug resistance gene MDR 1 and, as a result, tumors that express mutant p53 may become resistant to certain chemotherapeutic agents (Velculescu \& El Deiry 1996). While the effect of p53 on ER gene expression has not been studied, it has been shown that a high percentage of breast tumors with $\mathrm{p} 53$ mutations are often ER negative (Berns et al. 1996), suggesting that p53 may play a role in the progression of breast cancer to a more aggressive and anti-estrogen unresponsive phenotype. While p53 activity may play a role in determining ER status, it has also been shown that 
estradiol down-regulates the expression of p53 and ER $\alpha$ (Saceda et al. 1988, Hurd et al. 1995).

To determine if p53 regulates ER $\alpha$ gene expression, two approaches were used to alter the activity of p53 in MCF-7 cells. First, stable transfectants expressing an antisense p53 were established. Expression of antisense p53 in these cells resulted in a decrease in ER $\alpha$ protein as well as an increase in the resistance to the drug doxorubicin. In the second approach, over-expression of $\mathrm{p} 53$ was achieved by transiently transfecting MCF-7 cells with a wild-type p53 expression vector. This method produced an increase in ER $\alpha$ expression. These experimental approaches demonstrated that p53 up-regulates ER $\alpha$ gene expression. Data supporting the transcriptional control of ER $\alpha$ expression by p53 and a study of the ER $\alpha$ promoter sequences mediating these effects are presented. These data demonstrate a molecular link between the regulation of drug resistance by p53 and anti-estrogen responsiveness.

\section{Materials and Methods}

\section{Tissue culture}

Monolayer cultures of MCF-7 human breast cancer cells were grown in improved minimal essential medium (IMEM) supplemented with $5 \%(\mathrm{v} / \mathrm{v})$ fetal bovine serum (FBS). When the cells were $80 \%$ confluent, the medium was replaced with phenol red-free IMEM containing 5\% charcoal-treated calf serum (CCS) (Berthois et al. 1986). The CCS was pretreated with sulfatase and dextran-coated charcoal to remove endogenous steroids.

\section{ERa assays}

Enzyme immunoassay For determination of the concentration of ER $\alpha$ protein, MCF-7 cells were cultured and treated as described above. The amount of ER $\alpha$ protein was assayed using an enzyme immunoassay kit containing monoclonal antibodies to ER $\alpha$ from Abbott Laboratories (North Chicago, IL, USA). To obtain total ER $\alpha$, the cells were homogenized by sonication in a high salt buffer (10 mM Tris, $1.5 \mathrm{mM}$ EDTA, $5 \mathrm{mM} \mathrm{Na} \mathrm{MoO}_{4}, 0.4 \mathrm{M}$ $\mathrm{KCl}, 1 \mathrm{mM}$ monothioglycerol, and $2 \mathrm{mM}$ leupeptin). The homogenate was incubated on ice for $30 \mathrm{~min}$ and centrifuged at $10000 \mathrm{~g}$ for $1 \mathrm{~h}$ at $4{ }^{\circ} \mathrm{C}$. Aliquots of the total extracts were then analyzed according to the manufacturer's instructions.

Western blot Control and antisense p53-transfected MCF-7 clones were washed twice with PBS. Cells were scraped in PBS and centrifuged at $1000 \mathrm{~g}$ for $5 \mathrm{~min}$. The cellular pellet was resuspended in RIPA buffer $(150 \mathrm{mM}$ $\mathrm{NaCl}, 1 \% \mathrm{NP}-40,0 \cdot 5 \%$ deoxycholate, $0 \cdot 1 \% \mathrm{SDS}$, and $50 \mathrm{mM}$ Tris $(\mathrm{pH} 8)$ ) and proteases and phosphatase inhibitors were added. Cells were kept on ice for $30 \mathrm{~min}$ and centrifuged at $16000 \mathrm{~g}$ for $15 \mathrm{~min}$ at $4{ }^{\circ} \mathrm{C}$. The cellular pellet was discarded, and the protein content of the cell extract (supernatant) was determined using the Bradford method (Bio-Rad, Richmond, CA, USA). ER expression was determined by Western blot using monoclonal antibody anti-p53 (Oncogene Science, Uniondale, NY, USA) followed by enhanced chemiluminescence (Amersham International, Amersham, Bucks, UK) to develop protein bands.

\section{Plasmids}

The clones for the ER, pOR300 (Saceda et al. 1988), and the ribosomal protein human acidic ribosomal phosphoprotein (Saceda et al. 1988) have been described previously. The antisense p53 expression vector contains the complete p53 cDNA subcloned in the inverse orientation and under the control of the cytomegalovirus (CMV) promoter. The same vector containing the cDNA for neomycin resistance under the CMV promoter (kindly provided by Dr Daniel Eliahu) was used for selection. The wild-type p53 expression vector pC53-SN3 and the mutants pC53-273 and pC53-175 were a kind gift from Dr Bert Vogelstein (Baker et al. 1990). The ER $\alpha$ promoter constructs with the chloramphenicol acetyl transferase (CAT) reporter gene were a kind gift from Professor Pierre Chambon. The ER $\alpha$ promoter constructs expressing luciferase were a kind gift from Dr Ronald Weigel (DeConinck et al. 1995).

\section{Measurement of cellular ERa $m R N A$}

Total cellular RNA was extracted from MCF-7 cells by the method of Chomczynski \& Sacchi (1987). The amount of ER $\alpha$ mRNA was determined by an RNase protection analysis. In summary, homogeneously ${ }^{32} \mathrm{P}-$ labeled antisense molecules (cRNA) were synthesized in vitro from $\mathrm{pOR} 300$ (ER $\alpha$ riboprobe) and from p36B4 (ribosomal protein PO) using T7 polymerase. Total RNA $(60 \mu \mathrm{g})$ was hybridized for $12-16 \mathrm{~h}$ to the radiolabeled cRNA. After a 30 min digestion at $25^{\circ} \mathrm{C}$ with RNase A, ${ }^{32} \mathrm{P}-$ labeled cRNA probes protected from RNase digestion were resolved by electrophoresis on $6 \%$ polyacrylamide gels. The bands were visualized by autoradiography and quantified by optical densitometry. The amount of ER mRNA was normalized to the amount of the internal control 36B4, which is the cDNA of the human acidic ribosomal phosphoprotein $\mathrm{PO}$.

\section{Transfections}

To obtain stably transfected antisense p53 clones, MCF-7 cells were plated onto $6 \mathrm{~cm}$ Falcon plates at $6 \times 10^{5}$ cells/plate in phenol red-free IMEM containing 5\% FBS. After overnight incubation at $37^{\circ} \mathrm{C}$ and $5 \% \mathrm{CO}_{2}$, cells were washed three times with $1 \times$ PBS and overlaid with $3 \mathrm{ml}$ fresh IMEM containing 5\% FBS. A mixture of 
DNA/Superfect reagent (Qiagen) was prepared by mixing $2 \mu \mathrm{g}$ DNA with $5 \mu \mathrm{l}$ Superfect and serum-free IMEM was added up to $600 \mu \mathrm{l}$. After $10 \mathrm{~min}$ to allow for the DNA/Superfect complex formation, the $600 \mu \mathrm{l}$ DNA/ Superfect mixture was added to the $6 \mathrm{~cm}$ Falcon plate containing the cells in $3 \mathrm{ml}$ IMEM. After 3-h incubation at $37^{\circ} \mathrm{C}$ and $5 \% \mathrm{CO}_{2}$, cells were washed three times with $\mathrm{PBS}$ and the selection medium containing genticin (G-418) was added.

To determine the ER $\alpha$ promoter region mediating the p53 effect, a CAT reporter gene containing deletion mutants of the ER $\alpha$ promoter from -3200 to $+1 \mathrm{bp}$ was used. The amount of CAT expression was measured using an RNase protection assay. To further investigate the location of the elements regulated by p53, MCF-7 cells were transiently cotransfected with a luciferase reporter construct containing a deletion mutant of the ER $\alpha$ promoter from -3500 to $+210 \mathrm{bp}$ and with wild-type or mutant p53 expression vectors. The p53 effect was localized to the first $128 \mathrm{bp}$ of promoter A of the ER $\alpha$ gene. This region was subcloned into a CAT reporter gene construct containing an SV40 enhancer. Transfection assays were performed as described above.

\section{Results}

\section{Effect of p53 antisense expression on the concentration of ERa}

To determine the effects of p53 on ER $\alpha$ expression, MCF-7 cells were stably transfected with an expression vector containing the entire coding sequence of p53 in the antisense orientation under the transcriptional control of a CMV promoter. This vector also contained the neomycin resistance gene driven by a second CMV promoter. As a control, MCF-7 cells were stably transfected with the same vector lacking the antisense p53 sequence. After G-418 selection, nine control clones and 15 antisense p53-expressing clones were isolated. To determine the concentration of ER protein in the different clones, an enzyme immunoassay was performed. Data in Fig. 1A show that the antisense p53-transfected clones had, on average, greater than a $50 \%$ decrease in $\mathrm{ER} \alpha$ protein than the control transfected clones. These data suggested that a decrease in $\mathrm{p} 53$ expression results in a decrease in ER $\alpha$ expression in MCF-7 cells.

MCF-7 cells express wild-type p53 and, as a consequence, the amount of p53 in the cell is difficult to measure and for this reason it is complicated to detect a subsequent decrease in p53 following transfection with the antisense vector. To determine whether transfection with the antisense p53 vector disrupted expression of the endogenous gene, two experimental approaches were used. First, since wild-type p53 regulates the expression of the MDR1 product, P-glycoprotein, transfection of MCF-7 cells with an antisense p53 vector would be expected to decrease the expression of $\mathrm{p} 53$, to increase the expression of $\mathrm{P}$-glycoprotein, and consequently to increase the resistance to doxorubicin. In these experiments, nine control clones and 15 antisense p53 clones were treated with $10^{-7} \mathrm{M}$ doxorubicin (sigma) for 5 days. Cell survival was determined and expressed as percent of the number of cells originally plated. The results of this experiment are shown in Fig. 1B. The clones transfected with antisense p53 were approximately threefold more resistant to doxorubicin than the control transfectants, suggesting that expression of antisense p53 disrupts the expression of the endogenous gene leading to an increase in cell resistance to doxorubicin. Secondly, Western blot analysis of p53 expression was performed in several control and antisense p53-transfected MCF-7 clones. The results of these experiments are shown in Fig. 1C.

\section{Effect of wild-type p53 over-expression on ERa gene expression in MCF-7 cells}

To test whether an increase in p53 expression increases the expression of ER $\alpha, \mathrm{MCF}-7$ cells were transiently transfected with the wild-type p53 clone pC53-SN3 or the p53 mutants pC53-273 or pC53-175 (Baker et al. 1990). Clone pC53-273 contains a substitution of arginine to histidine at amino acid 273 which abolishes DNA binding (Kern et al. 1992), while clone pC53-175 contains an arginine to histidine substitution at amino acid 175 which prevents the protein from binding to other proteins (Kern et al. 1992). Transfection efficiency was monitored using a constitutive luciferase expression vector. Following the transfection, an RNase protection assay was employed to examine the effect of over-expression of wild-type p53 on the steady-state levels of ER $\alpha$ mRNA in MCF-7 cells. Changes in ER $\alpha$ mRNA were quantified by scanning densitometry and the data presented graphically in Fig. 2A as the ratio of the integrated ER $\alpha$ signal to the integrated ribosomal protein signal. Data were also normalized to the transfection efficiency. The RNase protection analysis demonstrated an increase in ER $\alpha$ mRNA expression in cells transfected with wild-type p53. To determine whether the increase in ER $\alpha$ gene expression is dependent on the DNA-binding capacity or protein-protein interaction of p53, MCF-7 cells were transiently transfected with two p53 mutants, clone pC53-273 does not bind to DNA while clone pC53-175 does not interact with other proteins. The data presented in Fig. 2A show an increase in ER $\alpha$ mRNA in MCF-7 cells transfected with either p53 mutant. However, while the pC53-273 mutant induced an increase in ER $\alpha$ mRNA similar to the increase observed with the wild-type p53, the pC53-175 mutantinduced increase was significantly smaller. These data suggested that the p53-induced up-regulation of ER $\alpha$ mRNA is not dependent on the ability of p53 to bind to DNA but interacts with other factors to regulate ER $\alpha$ gene transcription. 
To characterize the DNA-binding capabilities of both p53 mutant clones, control experiments were done by transiently cotransfecting MCF-7 cells with the wild-type p53 or the mutants pC53-273 or pC53-175 and a reporter gene under the control of 13 consensus p53-binding sites. The results in Fig. 2B show a sixfold increase in luciferase activity in MCF-7 cells transfected with wild-type p53 when compared with MCF-7 cells transfected with the reporter gene alone. A similar increase was obtained in MCF-7 cells transfected with the protein-protein interaction mutant; however, in MCF-7 cells transfected with the DNA-binding mutant, there was a minimal increase in luciferase activity. As expected, these data confirmed that pC53-273 does not bind efficiently to the p53 consensus

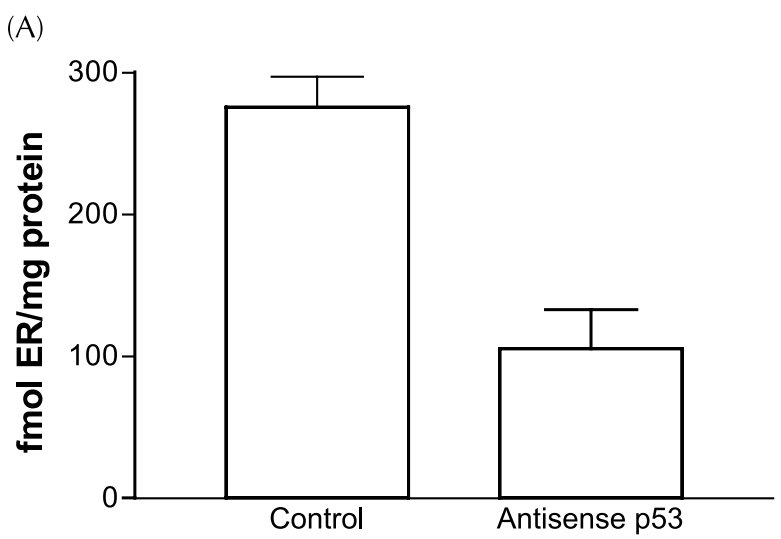

(B)

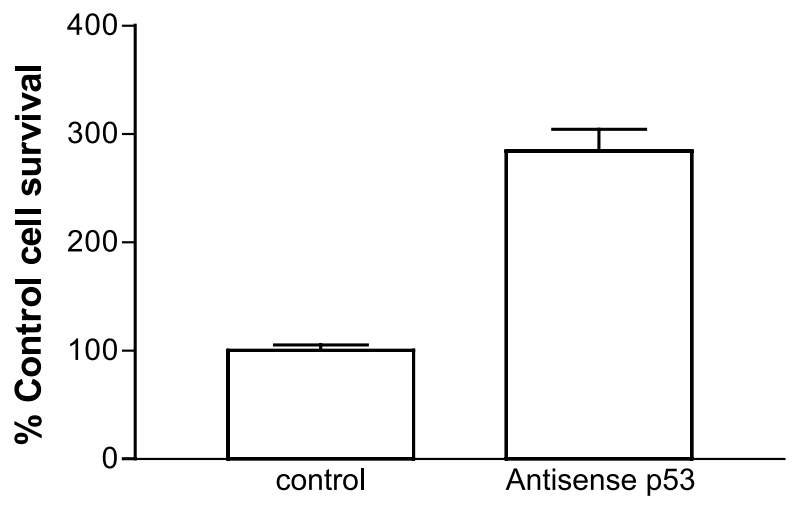

(C)

\section{P53}

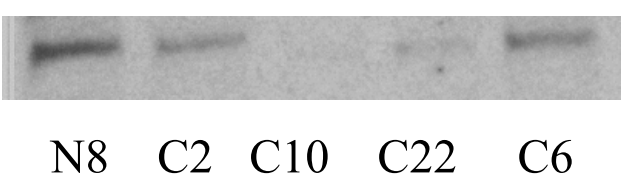

response sequences in MCF-7 cells, suggesting that the capacity of p53 to bind DNA is not necessary for the p53 regulation of $\mathrm{ER} \alpha$ gene expression.

\section{Identification of the ERa promoter region responsible for $p 53$ regulation}

Several ER $\alpha$ promoter constructs were used in order to determine if the effect of $\mathrm{p} 53$ on ER expression was due to a transcriptional regulation, and to identify the ER $\alpha$ promoter region mediating the p53 effect. To address these questions, MCF-7 cells were cotransfected with the wild-type p53 and constructs containing an ER $\alpha$ promoter region ranging from -3500 to $+210 \mathrm{bp}$ driving the expression of the luciferase reporter gene (DeConinck et al. 1995). The region from +1 to +210 of the ER $\alpha$ gene appears to be important for the basal activity of the $\mathrm{ER} \alpha$ promoter. Data using these constructs are shown in Fig. 3A. Cotransfection of p53 with deletion mutants of the ER $\alpha$ promoter from -3500 to $-350 \mathrm{bp}$ resulted in a six- to sevenfold increase in luciferase expression. When p53 was cotransfected with the deletion mutants of the $\mathrm{ER} \alpha$ promoter from -289 to $-128 \mathrm{bp}$, there was a threefold increase in luciferase expression. The ability of p53 to activate ER $\alpha$ promoter was lost when the promoter was deleted to $-40 \mathrm{bp}$. Taken together, these data suggested that at least two elements in the ER promoter are responsible for $\mathrm{p} 53$ regulation, one of them is located between -128 and $-40 \mathrm{bp}$ and the second one is located between -350 and $-289 \mathrm{bp}$. To determine whether p53 regulates ER $\alpha$ expression by binding to DNA or through protein-protein interactions with other transcription factors, ER $\alpha$ promoter constructs were cotransfected with p53 mutants. Cotransfection of the

Figure 1 Effect of antisense p53 expression on the concentration of ER $\alpha$ in MCF-7 cells. MCF-7 cells were grown in IMEM medium supplemented with 5\% FCS. At $80 \%$ confluence, the medium was changed to phenol red-free IMEM and 5\% CCS. MCF-7 clones stably expressing antisense p53 were obtained as described in Materials and Methods. Nine control clones and 15 antisense p53 clones were isolated and assayed. (A) Effect of antisense p53 expression on the concentration of ER $\alpha$. The concentration of ER $\alpha$ protein was determined in the MCF-7 clones expressing antisense p53 as well as in the transfected control cells using an enzyme immunoassay as described in Materials and Methods. Values are means \pm S.D. of ten control and 15 antisense p53 MCF-7 cellular clones. ${ }^{*} P<0 \cdot 05$. (B) Effect of antisense p53 expression on doxorubicin resistance. To demonstrate the expression of antisense p53, the resistance to doxorubicin was determined. Cells were treated with $10^{-7} \mathrm{M}$ doxorubicin for 5 days. Cell viability was measured and expressed as percent survival (means \pm S.D., $n=10$ ). ${ }^{*} P<0 \cdot 05$. (C) p53 protein levels determined by Western blot in control and antisense p53-transfected MCF-7 clones. Lane 1, N8 control clone, MCF-7 cells only transfected with the plasmid that confers resistance to G-418. Lanes 2-5, antisense p53-transfected clones C2, C10, C22, and C6, cells transfected with the same plasmid as N8 but containing also the antisense p53 construct. 
(A)

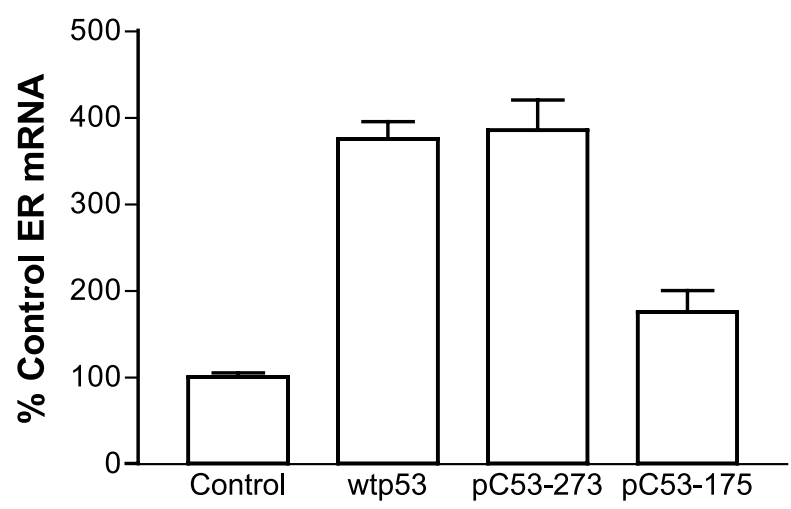

(B)

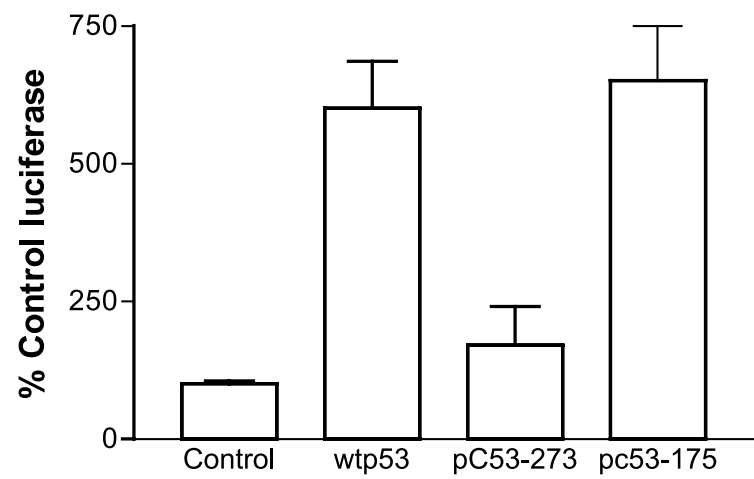

Figure 2 Effect of wild-type p53 (wtp53) over-expression on ER $\alpha$ gene expression in MCF-7 cells. MCF-7 cells were grown as described in Fig. 1. (A) Effect of wild-type p53 over-expression on ER $\alpha$ gene expression. MCF-7 cells were transiently cotransfected with the wild-type p53 (wtp53; pC53-SN3), the DNA-binding mutant (pC53-273), or the protein-protein interaction mutant (pC53-175) and a constitutive expression vector for luciferase (Control-cells transfected only with a constitutive expression vector for luciferase). An RNase protection assay was performed to determine the amount of ER $\alpha$ mRNA. The data were quantified as the ratio of the integrated $E R \alpha$ signal to the integrated ribosomal protein $\mathrm{PO}$ signal and normalized to the transfection efficiency as measured by luciferase activity in each sample. Values are means \pm S.D. of five separate experiments. ${ }^{*} P<0 \cdot 05$. (B) Effect of mutations on the transcriptional activity of p53. MCF-7 cells were transiently cotransfected with the wild-type p53 (wtp53; pC53-SN3), the DNA-binding mutant (pC53-273), or the protein-protein interaction mutant ( $\mathrm{pC} 53-175)$ and a reporter gene containing 13 consensus p53 binding sites controlling the expression of luciferase (Control). Luciferase activity was determined. Values are means \pm S.D. $(n=6) .{ }^{*} P<0 \cdot 05$.

ER $\alpha$ promoter constructs -3200 to +210 or -128 to +210 with the pC53-273 mutant that does not bind to DNA yielded similar results to those obtained with the wild-type p53 (Fig. 3B). In contrast, cotransfection of the promoter constructs with the pC53-175 mutant that prevents p53 binding to other proteins showed a significant decrease in the induction of luciferase activity, suggesting that $\mathrm{p} 53$ regulates transcription of the ER $\alpha$ through a protein-protein interaction within the proximal promoter region of the gene.

To further define the promoter region, deletion mutants that do not contain the +1 to +210 region of the gene were used. These constructs contain deletions of the ER $\alpha$ promoter from -3200 to $-40 \mathrm{bp}$ driving the expression of a CAT reporter gene. Similar to the previous results, cotransfection of the wild-type p53 with deletion mutants of the ER $\alpha$ promoter constructs from -3200 to $-128 \mathrm{bp}$ showed a two- to threefold increase in CAT mRNA levels (data not shown), suggesting that the region +1 to +210 was not necessary for the p53 response. To further demonstrate that this region is involved in mediating the p53 effect, MCF-7 cells were cotransfected with the wild-type p53 and a construct containing the first $128 \mathrm{bp}$ of the ER $\alpha$ promoter region driving the expression of the CAT reporter gene (Stoica et al. 1999). Data presented in Fig. 3D showed a clear increase in CAT activity in MCF-7 cells transfected with the wild-type p53 as compared with MCF-7 cells transfected with the reporter gene alone, providing additional evidence that the effects of $\mathrm{p} 53$ on ER $\alpha$ gene transcription are mediated by a region in the proximal promoter. To establish the role of endogenous p53 in the response, antisense p53 was transiently transfected with a construct containing the first $519 \mathrm{bp}$ of the ER $\alpha$ promoter into MCF-7 cells. Compared with control transfectants there was a dramatic decrease in CAT mRNA levels (Fig. 3C). Taken together, these data suggested that the effect of $\mathrm{p} 53$ on ER $\alpha$ expression is due in part to a transcriptional event, and that at least one element mediating this regulation is located within the first $128 \mathrm{bp}$ of the ER $\alpha$ promoter.

\section{Discussion}

The results presented herein demonstrate that p53 upregulates ER $\alpha$ expression in the human breast cancer cell line MCF-7. These data showed that transfection of MCF-7 cells with a wild-type p53 expression vector leads to an increase in the level of ER $\alpha$ mRNA. The ability of p53 to regulate ER $\alpha$ expression was further demonstrated in cells stably transfected with an antisense p53 expression vector; in the antisense clones, the amount of $\mathrm{ER} \alpha$ protein was significantly decreased as compared with the control transfected clones. The effect of p53 on ER $\alpha$ expression appears to be due to a transcriptional effect. Similar to the increase in ER $\alpha$ mRNA, p53 increased the transcription of a reporter gene that was under the control of the ER $\alpha$ promoter. Furthermore, transient transfection of the ER $\alpha$ promoter into MCF-7 clones stably transfected with antisense p53 also demonstrated the ability of p53 to regulate the ER $\alpha$ promoter. The effect of $\mathrm{p} 53$ on ER $\alpha$ promoter activity appears to be mediated through proteinprotein interactions rather than through binding to a 
(A)

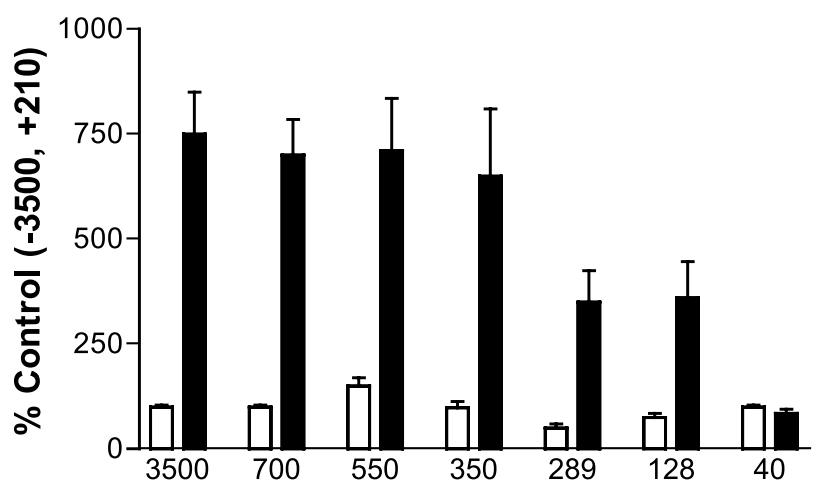

(C)

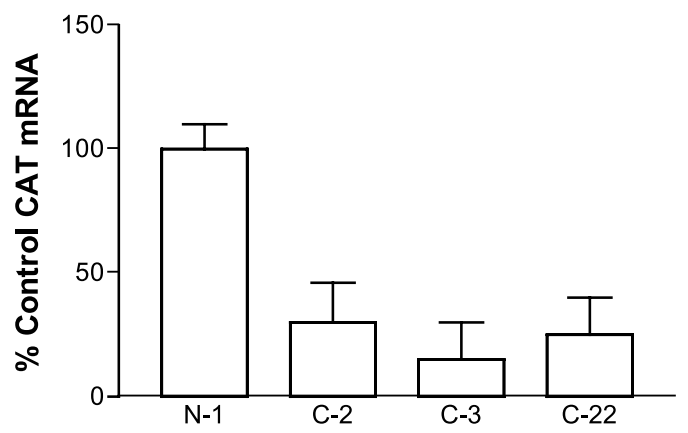

(B)

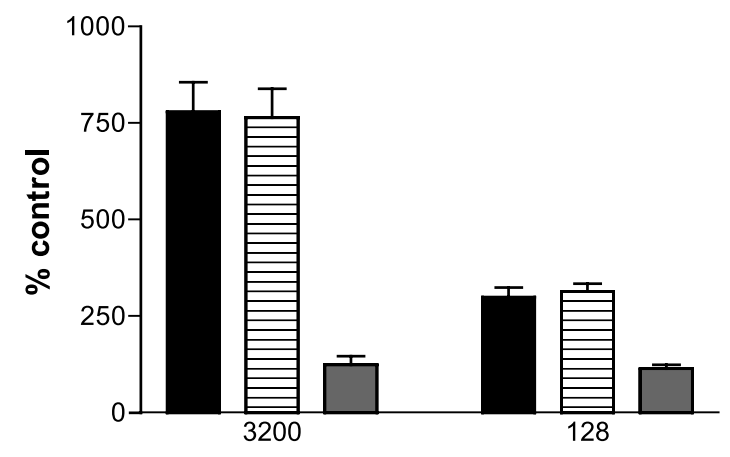

(D)

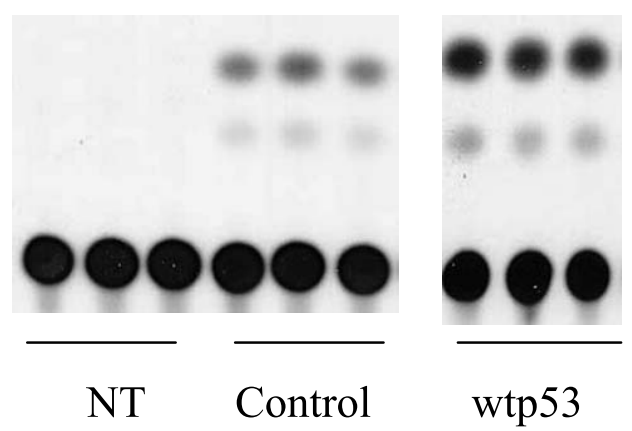

Figure 3 Identification of the ER promoter region responsible for p53 regulation. MCF-7 cells were grown as described in Fig. 1. (A) MCF-7 cells were cotransfected with wild-type p53 and deletion mutants of the ER $\alpha$ promoter ( -3500 to $-40 \mathrm{bp})$ driving the expression of the luciferase gene. Results (luciferase expression) are expressed as percent activity of control cells transfected with the -3500 to +210 bp reporter. Values are means \pm s.D. $(n=6)$. Open bars, control; solid bars, p53. (B) MCF-7 cells were cotransfected with the wild-type p53 (pC53-SN3; solid bars), the DNA-binding mutant (pC53-273; striped bars), or the protein-protein interaction mutant (pC53-175; shaded bars) and with two different ER $\alpha$ promoter constructs: -3200 to +210 (3200) and -128 to +210 (128). Induction of luciferase activity was expressed as percent of control non-transfected MCF-7 cells. Values are means \pm S.D. $(n=6)$. (C) MCF-7 cells were transiently cotransfected with an antisense p53 vector and an ER $\alpha$ promoter construct containing -519 to $+1 \mathrm{bp}$. CAT mRNA levels were determined by RNase protection. Values are means \pm S.D. $(n=4)$. N-1, reporter construct; C- $1,-2,-3$, reporter constructs plus antisense p53. (D) MCF-7 cells were cotransfected with the wild-type p53 and a construct containing the first 128 bp of the ER $\alpha$ promoter driving the expression of the CAT reporter gene. CAT activity was also determined in cells transfected with the reporter gene alone and in control non-transfected MCF-7 cells. NT, non-transfected; C, control; wtp53, wild-type p53.

response element in DNA, since the effects on the ER $\alpha$ promoter and mRNA were observed in cells transfected with a p53 mutant that does not bind DNA (Kern et al. 1992). In contrast, transfection of a p53 mutant that binds to DNA but does not interact with other proteins results in a decrease in ER $\alpha$ promoter activity, suggesting that protein-protein interactions are important for $\mathrm{p} 53$ regulation of $\mathrm{ER} \alpha$ expression.

The tumor suppressor p53 plays an integral role in the control of cell cycle progression, maintenance of DNA integrity, and induction of apoptosis (Zhan et al. 1993, Yonish-Rouach et al. 1995). A variety of DNA-damaging agents can induce p53 which, in turn, functions to arrest cell cycle progression allowing for the repair of DNA damage or, alternatively, to induce apoptosis (Zhan et al. 1993, Yonish-Rouach et al. 1995). Recent data also show that p53 is activated by compounds that stabilize microtubules such as taxol (Tishler et al. 1995, Martin et al. 2004). p53 functions as a transcription factor that is capable of both activating and repressing the transcription of a number of genes (Ludes-Meyers et al. 1996, Velculescu \& El Deiry 1996, Wang et al. 2001). More recent studies have shown that $\mathrm{p} 53$ is also involved in the regulation of splicing (Moyret-Lalle et al. 2001). The ability of p53 to 
regulate gene transcription is mediated either by its ability to bind directly to DNA or to interact with other transcription factors such as the TATA binding protein, CCAAT binding protein, and SP1 (Velculescu \& El Deiry 1996). In the case of the ER $\alpha$ promoter, p53 appears to increase transcription through a protein-protein interaction.

Two putative sites in the ER $\alpha$ promoter were identified that could mediate the effects of $\mathrm{p} 53$. The first site lies in a region between -128 and $-40 \mathrm{bp}$ and the second site lies in a region between -350 and $-289 \mathrm{bp}$. Interestingly, the more proximal site also mediates the effects of taxol on ER $\alpha$ expression. Treatment of MCF-7 cells with taxol increases the expression of p53 as well as the activity of the ER $\alpha$ promoter (Martin et al. 2004). The taxolinduced increase in ER $\alpha$ promoter activity involves the formation of a complex containing p53 with a site in promoter A. The complex binding site is located between -70 and $-40 \mathrm{bp}$ and is flanked by a TATA box and an NF-1 binding site. Taken together, it is reasonable to suggest that the taxol-induced increase in $\mathrm{ER} \alpha$ promoter activity is mediated through the activation of p53 which activates the ER $\alpha$ promoter through a protein-protein interaction with a factor(s) that binds to the -70 to $-40 \mathrm{bp}$ region of promoter A. The ability of p53 to also interact with NF-1 and the TATA binding protein (Velculescu \& El Deiry 1996) supports this model.

The p53 gene is mutated in approximately $50 \%$ of all tumors (Hollstein et al. 1991, Zhan et al. 1993, Velculescu \& El Deiry 1996) and many of these mutations have been shown to be oncogenic (Baker et al. 1990, Zhan et al. 1993, Velculescu \& El Deiry 1996). In breast cancer, p53 mutations are associated with a decrease in disease-free and overall survival of patients (Sirvent et al. 2001). Mutations in p53 are also associated with doxorubicin resistance (Sirvent et al. 2001) and with the lower efficacy of adjuvant therapy with tamoxifen in lymph node-positive patients (Berns et al. 2000). Although p53 mutants isolated from BRCA-associated breast cancer appear to maintain many of the wild-type functions of the gene, these mutants have the ability to induce tumors in rat embryo fibroblasts (Smith et al. 1999). The ability of p53 to control the expression of ER $\alpha$ suggests that specific p53 mutations in breast tumors may contribute not only to oncogenesis and drug resistance but also to the more aggressive phenotype associated with the loss of ER expression. Interestingly, a high percentage of breast tumors with p53 mutations are ER negative (Berns et al. 1996). In addition, mutations in p53 are associated with re-expression of ER in the breast cancer cell line MCF-10A. Together with the present study, these studies suggest that p53 not only regulates the ER $\alpha$ promoter but may play a role in determining ER status. It may be postulated that p53 plays a role in the progression of breast cancer from a hormone-dependent phenotype to a more aggressive hormone-unresponsive phenotype.

\section{Acknowledgements}

This work was supported, in part, by NIH CA59493, Generalitat Valenciana, GVDOC98-VS-23-13 and Fondo de Investigaciones de la Seguridad Social, FIS 01/0168.

\section{References}

Allegra JC \& Lippman ME 1980 Estrogen receptor status and the disease-free interval in breast cancer. Recent Results in Cancer Research 71 20-25.

Baker SJ, Markowitz S, Fearon ER, Willson JK \& Vogelstein B 1990 Suppression of human colorectal carcinoma cell growth by wild-type p53. Science 249 912-915.

Berns EM, Klijn JG, Smid M, van Staveren IL, Look MP, van Putten WL \& Foekens JA 1996 TP53 and MYC gene alterations independently predict poor prognosis in breast cancer patients. Genes Chromosomes. Cancer 16 170-179.

Berns EM, Foekens JA, Vossen R, Look MP, Devilee P, Henzen-Logmans SC, van Staveren IL, van Putten WL, Inganas M, Meijer-van Gelder ME, Cornelisse C, Claassen CJ, Portengen H, Bakker B \& Klijn JG 2000 Complete sequencing of TP53 predicts poor response to systemic therapy of advanced breast cancer. Cancer Research 60 2155-2162.

Berthois Y, Katzenellenbogen JA \& Katzenellenbogen BS 1986 Phenol red in tissue culture is a weak estrogen: implications concerning the study of estrogen-responsive cells in culture. PNAS 83 2496-2500.

Chomczynski P \& Sacchi N 1987 Single-step method of RNA isolation by acid guanidinium thiocyanante-phenol-chloroform extraction. Analytical Biochemistry 162 156-159.

DeConinck EC, McPherson LA \& Weigel RJ 1995 Transcriptional regulation of estrogen receptor in breast carcinomas. Molecular and Cellular Biology 15 2191-2196.

DeSombre ER \& Jensen EV 1980 Estrophilin assays in breast cancer: quantitative features and application to the mastectomy specimens. Cancer 46 2783-2788.

Hollstein M, Sidransky D, Vogelstein B \& Harris CC 1991 p53 mutations in human cancers. Science 253 49-53.

Hurd C, Khattree N, Alban P, Nag K, Jhanwar SC, Dinda S \& Moudgil VK 1995 Hormonal regulation of the p53 tumor suppressor protein in T47D human breast carcinoma cell line. Journal of Biological Chemistry 270 28507-28510.

Kern SE, Pietenpol JA, Thiagalingam S, Seymour A, Kinzler KW \& Vogelstein B 1992 Oncogenic forms of p53 inhibit p53-regulated gene expression. Science 256 827-830.

Ludes-Meyers JH, Subler MA, Shivakumar CV, Munoz RM, Jiang P, Bigger JE, Brown DR, Deb SP \& Deb S 1996 Transcriptional activation of the human epidermal growth factor receptor promoter by human p53. Molecular and Cellular Biology 16 6009-6019.

Martin MB, Angeloni SV, Garcia-Morales P, Sholler PF, Castro-Galache MD, Ferragut JA \& Saceda M 2004 Taxol regulation of estrogen receptor- $\alpha$ expression in MCF-7 cells. Journal of Endocrinology 180 497-504 (see this issue).

Moyret-Lalle C, Duriez C, Van Kerckhove J, Gilbert C, Wang Q \& Puisieux A 2001 p53 induction prevents accumulation of aberrant transcripts in cancer cells. Cancer Research 61 486-488.

Osborne CK, Yochmowitz MG, Knight WAI \& McGuire WL 1980 The value of estrogen and progesterone receptors in the treatment of breast cancer. Cancer 46 2884-2888.

Paridaens R, Sylvester RJ, Ferrazzi E, Legros N, LeClercq G \& Hensen JC 1980 Clinical significance of the quantitative assessment of estrogen receptors in advanced breast cancer. Cancer 46 2889-2895.

Saceda M, Lippman ME, Chambon P, Lindsey RK, Pongliktmongkol M, Puente M \& Martin MB 1988 Regulation of the estrogen 
receptor in MCF-7 cells by estradiol. Molecular Endocrinology 2 $1157-1162$.

Sirvent JJ, Fortuno-Mar A, Olona M \& Orti A 2001 Prognostic value of 553 protein expression and clinicopathological factors in infiltrating ductal carcinoma of the breast. A study of 192 patients. Histology and Histopathology 16 99-106.

Smith PD, Crossland S, Parker G, Osin P, Brooks L, Waller J, Philp E, Crompton MR, Gusterson BA, Allday MJ \& Crook T 1999 Novel p53 mutants selected in BRCA-associated tumours which dissociate transformation suppression from other wild-type p53 functions. Oncogene 18 2451-2459.

Stoica A, Saceda M, Fakhro A, Solomon HB, Fenster BD \& Martin MB 1999 Regulation of estrogen receptor-a gene expression by 1,25-dihydroxyvitamin D in MCF-7 cells. Journal of Cellular Biochemistry 75 640-651.

Tishler RB, Lamppu DM, Park S \& Price BD 1995

Microtubule-active drugs taxol, vinblastine, and nocodazole increase the levels of transcriptionally active p53. Cancer Research $\mathbf{5 5}$ $6021-6025$.
Velculescu VE \& El Deiry WS 1996 Biological and clinical importance of the p53 tumor suppressor gene. Clinical Chemistry $\mathbf{4 2}$ 858-868.

Wang L, Wu Q, Qiu P, Mirza A, McGuirk M, Kirschmeier P, Greene JR, Wang Y, Pickett CB \& Liu S 2001 Analyses of p53 target genes in the human genome by bioinformatic and microarray approaches. Journal of Biological Chemistry 276 43604-43610.

Yonish-Rouach E, Deguin V, Zaitchouk T, Breugnot C, Mishal Z, Jenkins JR \& May E 1995 Transcriptional activation plays a role in the induction of apoptosis by transiently transfected wild-type p53. Oncogene 11 2197-2205.

Zhan Q, Carrier F \& Fornace AJ Jr 1993 Induction of cellular p53 activity by DNA-damaging agents and growth arrest. Molecular and Cellular Biology 13 4242-4250.

Received in final form 3 October 2003

Accepted 27 November 2003 